\title{
Redaksjonelt
}

\section{Ny årgang - Acta Didactica Norge 2008}

Velkommen til 2. årgang av Acta Didactica Norge! I år publiseres artiklene fortløpende etter at de er fagvurdert og redigert, og samles i en årgang. Dermed kortes publiseringstiden ytterligere ned.

Vi har nå gleden av å presentere fem nye artikler og en bokomtale. I artikkelen "Didaktikk - fagdidaktikk, anstrengte eller fruktbare forhold?" skriver Bjørg Brandtzæg Gundem om ulike definisjoner av didaktikk i spenningsfeltet mellom pedagogikk og fagdidaktikk, og tar for seg hver av disiplinene ut fra et historisk og teoretisk så vel som et aktuelt skolepolitisk og praktisk perspektiv. Her diskuterer hun også Tomas Englunds didaktikkbegrep, blant annet med henvisning til hans artikkel "Om relevansen av begreppet didaktikk” i Vol 1, Nr 1 (2007).

Gundem konkluderer med at fagdidaktiske overveielser finner sted i skjæringspunktet mellom pedagogisk teori og fagvitenskap, mellom allmenn didaktisk teori og opplæringsvirkeligheten. Forholdet mellom teori og praksis tematiseres i Jon Magne Vestøls artikkel "Didaktiske modeller i lærerutdanningen. En analyse av lærerstudenters praksisrefleksjon”. Her studerer han hvordan lærerstudenter bruker didaktiske modeller i sin refleksjon over egen praksis, og artikkelen diskuterer om modellene inngår i en konserverende forståelse av praksis eller praksisutfordrende refleksjon. Selv om Vestøl er seksjonsredaktør i tidsskriftet, har artikkelen hans selvsagt vært gjennom samme anonyme fagfellevurdering og grundige redaksjonelle bearbeiding som øvrige artikler.

I artikkelen "Mot eit moderne norskfag” tar Magne Rogne for seg tekstbegrepet i norskfaget gjennom analyser av læreplanene i norsk fra 1939 fram til i dag. Norskfaget har endret seg i tråd med samfunnsutviklingen når det gjelder hvilke teksttyper det er viktig å arbeide med, konstaterer Rogne, som også finner at kravene til å mestre tekstproduksjon i dagens plan ikke er i samsvar med overordnede mål for faget.

De to neste artiklene vi presenterer i denne omgangen, har begge utgangspunkt i språkdidaktikk, hovedsakelig knyttet til engelskopplæring, og er derfor skrevet på engelsk. I ”A Case for Improved Reading Instruction for Academic English Reading Proficiency" presenterer Glenn Ole Hellekjær en studie av leseferdighet i engelsk i videregående skole som viste at to tredeler av elevene ikke innfridde internasjonale krav til lesing på akademisk nivå, mens elever som hadde fått deler av fagopplæringen på engelsk, lyktes bedre. Hellekjær påviser sammenhenger mellom de svake testresultatene og lite fokus på leseopplæring på engelsk i videregående skole. Angela Hasselgreen og Ion Drew tar for seg den første engelskopplæringen i artikkelen "Young language learner (YLL) research: An overview of some international and national approaches". Med 
utgangspunkt i en økende oppmerksomhet rettet mot tidlig språkinnlæring gir de en oversikt over nyere internasjonal og nasjonal forskning på dette feltet. De påpeker et behov for forskning på flere aspekter ved tidlig opplæring i engelsk og andre fremmedspråk i Norge.

Vi vil også takke Rune Andreassen for omtalen av Astrid Roe: Lesedidaktikk - etter den første leseopplceringen (Universitetsforlaget). Det er den første bokomtalen i tidsskriftet, og vi ser fram til flere.

I løpet av høsten vil redaksjonen presentere flere interessante artikler. Til nå er omtrent like mange manus akseptert som avvist gjennom den redaksjonelle prosessen. Redaksjonen legger vekt på den gode kvaliteten i de publiserte artiklene samtidig som vi ser muligheten for framtidige artikler i de manus som avvises. I dette arbeidet har vi meget god hjelp av velvillige og grundige fagkonsulenter. Sammen med vår dyktige redaksjonsleder arbeider vi også med å forbedre de redaksjonelle prosedyrene, særlig gjelder dette utviklingen av stringente retningslinjer for referanser.

Det er etablert et redaksjonsråd for tidsskriftet. Til leder har rådet valgt Ove Haugaløkken fra Program for lærerutdanning ved NTNU. Redaksjonsrådet vil trekke opp linjene for tidsskriftets arbeid og bistå med råd i den daglige driften.

Oslo, august 2008

Rita Hvistendahl

Ansvarlig redaktør 